\title{
Right to Access to Information and the Issue of Ensuring Environmental Security in Vietnam
}

\author{
Luu Quoc Thai
}

\begin{abstract}
In the present day, environmental security is a global issue. For this reason, Vietnam has also formally stipulated the issue of "environmental security" in the Law on Environmental protection 2014. One of the important requirements for effective environmental protection, ensuring environmental security is the effective implementation of information publicization as well as the right to access to information related to environment of people in a society. However, in the Vietnamese Law on Environmental Protection 2020 (effective from January 1, 2022 replacing the Law on Environmental Protection 2014), the concept of "environmental security" no longer exists and many regulations on Environmental information disclosure has also been changed. This raises doubts about the ability to access information to protect environmental security in the near future. Therefore, this article will analyze the provisions of current Vietnamese Environment law on the issue of access to information in relation to ensuring environmental security in Vietnam. At the same time, the article also provides a preliminary assessment of relevant new regulations to contribute to the improvement of the law on access to environmental information in Vietnam.
\end{abstract}

Key words - Access, Environmental security, Information, Law, Vietnam.

\section{INTRODUCTION}

Environmental security is a global issue today [1]. For Vietnam in recent years, pollution, degradation, and even environmental incidents have occurred more and more, with increasing severity. This situation has led to instability in political, economic, and social life [2]. These are bad signs in terms of environmental security. Aware of this problem, the State of Vietnam has officially regulated "environmental security" and specific mechanisms and activities to ensure the environmental security in the Law on Environmental Protection 2014. One of the important requirements for effective environmental protection and environmental security is the enforcement of information disclosure as well as the right to access to information related to the environment for the whole society.

At the international level, in 1998, at the Fourth Ministerial Conference on "Environment for Europe" taking place in the city of Aarhus (Denmark), the Convention on Access to Information, Public Participation in decision making and access to justice on environmental issues (Aarhus Convention) was signed with the participation of 39 countries and the European Community. The objective of the Convention is "to contribute to the protection of the right of all people of present and future generations to live in an environment suitable for their health and well-being" [3].

In Vietnam, the current law has many specific regulations on the issue of publicizing environmental information, creating conditions for the population and society to access and monitor the State's environmental protection activities and other subjects. Important types of environmental information that determine the effectiveness of environmental protection (such as strategic environmental assessment, environmental impact assessment, waste management, pollution status, etc.) have been required to be made public. The responsibility to disclose information has been also specified.

However, the mechanism to ensure the disclosure of environmental information is still not clearly defined and inappropriate, especially the legal responsibility of entities who do not comply with regulations on information provision. This reason has made the right to access environmental information only a formality and is the cause of continued environmental pollution on a large scale and increasing seriously, and consequently environmental security is still not guaranteed. For that reason, this article will present and analyze the current legal provisions on environmental information, the right to access environmental information in relation to ensuring environmental security in Vietnam. The article will also propose specific solutions to ensure the right to access environmental information in order to contribute to the ensuring environmental security in Vietnam in the future.

\section{Methodology}

The article is based on the theory of "sustainable development" as stated in the Stockholm Declaration 1972 (at the Conference on the Human Environment held in the Swedish capital in 1972). It is development that meets the needs of the present without compromising the satisfaction of the needs of future generations - the development without destruction [4]. Based on this theory, the concept of "sustainable development" has also been officially explained in the Vietnamese Law on Environmental Protection 2014 (Clause 4, Article 3) [5].

The article also takes reference to Aarhus Convention 1998 of The United Nations Economic Commission for Europe. The Aarhus Convention has been establishing a number of rights of the public (individuals and their associations) with regard to the environment. Those are the rights of everyone 
to receive environmental information that is held by public authorities ("access to environmental information"); the right to participate in environmental decision-making. Arrangements are to be made by public authorities to enable the public affected and environmental non-governmental organisations to comment on ("public participation in environmental decision-making"); and the right to review procedures to challenge public decisions that have been made without respecting the two aforementioned rights or environmental law in general ("access to justice") [6].

These above theories show that, information transparency to ensure environmental security is a decisive condition for sustainable development. To achieve this, sometimes we must accept the sacrifice of economic benefits to ensure the safety of the environment.

\section{DISCUSSION AND RESULTS}

\section{A. The relationship between the Right to Access to} Information and The Issue of Environmental Security

The human right to a healthy environment is one of the central principles of international environmental law, which has long been recognized in the 1972 Stockholm Declaration (Declaration of the United Nations Conference on the Human environment). This principle is reaffirmed many times in international law (for example, Principle 1 of the Rio de Janeiro Declaration 1992) and has been specified by countries in their legislation. Recently, the Vietnamese Constitution 2013, in Article 43, officially stipulates: "Everyone has the right to live in a healthy environment and has the obligation to protect the environment". This regulation shows that, in order to have a healthy environment to live in, people must protect the environment well. To do this, people in society must have full and timely access to relevant information, especially about adverse impacts on the environment.

According to the provisions of Vietnamese law, "Environmental security is the assurance that there is no major impact of the environment on the political, social stability and economic development of the country" (Clause 28, Article 3 of [5]). According to some other authors, "Environmental security is the state in which an environmental system is capable of ensuring safe living conditions for people in that system". An insecurity of an environmental system can be caused by natural causes (disasters) or due to human activities (exploitation of natural resources, discharge of toxic substances into the environment causing pollution, environmental degradation, biodiversity loss, etc.) or a combination of both of the above reasons [7]. This concept is basically similar to the concept of environmental security in many countries around the world, according to which: "Environmental security is the state of protection of vital interests of the individual, society, natural environment from threats resulting from anthropogenic and natural impacts on the environment" [8]. Thus, environmental security can be broadly understood as ensuring the environment is not polluted according to the provisions of law so that people can have a healthy living environment.

In fact, the right to information and access to information has been considered as a "foundation" for the exercise of other human rights. Because of this importance, more than
100 countries around the world (including Vietnam) have enacted the Law on Access to Information [9]. As we all know, along with economic development, pollution, degradation, and even major environmental problems are taking place very seriously in developing countries like Vietnam. For many years, experts have issued many warnings about Vietnam's worsening environmental situation, which is destabilizing economic, political, and social life. That is the reason why conflicts and lawsuits stemming from environmental pollution are increasing and becoming more and more serious [10]. The state of environmental insecurity stems from many reasons, of which the main ones are the risks of pollution or environmental incidents that have not been prevented in time. The main cause of this phenomenon is that the community and society do not grasp the necessary information related to polluting projects and activities. For example, the case of Formosa discharging untreated industrial waste in 2016 caused marine pollution in many central provinces of Vietnam, causing great damage to the environment and fishermen. In this case, the issue of providing information on licensing for pipelines that discharged directly into the sea was sometimes inconsistent and unclear [11]. This case has also led to many protests which were considered disruptive because Vietnam does not have a law on protests [12]. Another typical case is the sinking of sludge from Vinh Tan thermal power plant (Binh Thuan province) in which many scientists were impersonated and included in the Evaluation Council of the project's environmental impact assessment report until the information was "leaked", the project was stopped [13]. If this project continued to be implemented, it might cause great and longterm harm to the marine environment [14]. Therefore, in order to protect the healthy living environment for people, ensuring environmental security, public information and ensuring the right to access information about the environment are crucial.

\section{B. Current Status of Vietnam's Law on Environmental Information Disclosure and the Right to Access Environmental Information}

The publicity and provision of information about the environment had been officially regulated since the Law on Environmental Protection 2005 (see Article 103 of [15]). This content has been inherited by the Law on Environmental Protection 2014 and regulated in great detail. We will consider each related issue in turn.

\section{1) The concept of environmental information}

Previously, according to 18 Clause 3 of the Law on Environmental Protection 2005 (which has expired), "Environmental information includes data and data on environmental components; on reserves, ecological values and economic values of natural resources; on environmental impacts; on waste; on the extent of environmental pollution, degradation, and information on other environmental issues". After that, Clause 29, Article 3 of the Law on Environmental Protection 2014 defines environmental information much more concisely, that: "Environmental information is data and data about the environment in the form of symbols, letters, numbers, images, sounds or the like". This definition was then concretized in Clause 1, Article 128 of the Law on Environmental Protection 2014: "Environmental information 
includes data and data on environmental components, impacts on the environment, policies and laws on environmental protection, environmental protection activities".

In comparison with the Law on Environmental Protection 2005, the provisions of the Law on Environmental Protection 2014 on environmental information are more general, especially with the addition of information of "environmental policy and protection law". However, the shortcoming of the current regulation on this issue is that it does not clearly mention "sensitive" environmental information in concepts such as "about waste; level of environmental pollution and degradation" in the way that the Law on Environmental Protection 2005 stipulated, although these contents were later also stipulated in Article 131 of the Law on Environmental Protection 2014. This can be a "loophole" for polluting information to be "hidden", affecting society's access to environmental information ${ }^{1}$. Or, if environmental pollution information is not disclosed in time, it will affect the health and life of people in the polluted area, for example, there were "cancer villages" in Vietnam due to water pollution [16].

2) The types of environmental information to be disclosed and the right to request and the responsibility to provide environmental information

According to Clause 1, Article 131 of the Law on Environmental Protection 2014, environmental information that must be made public (except for information on the list of state secrets) includes:

a) strategic environmental assessment report, environmental impact assessment and environmental protection plan;

b) information on waste sources, waste, waste treatment;

c) areas where the environment is polluted, degraded at a serious and especially serious level, an area at risk of environmental incidents;

d) environmental reports;

d) result of inspection and test on environmental protection.

Compared with the Law on Environmental Protection 2005, the scope of environmental information to be publicized of the Law on Environmental Protection 2014 has been expanded to include inspection and examination results on environmental protection [17]. It can be seen that the above environmental information, if fully and timely disclosed, will make a great contribution to environmental protection activities.

In addition, the responsibility to provide and publicize environmental information is also specified in Article 130 of the Law on Environmental Protection 2014. Specifically:

"1. Organizations and individuals that manage industrial parks, export processing zones, hi-tech parks, industrial clusters, production, business and service establishments that are required to make environmental impact assessment reports are responsible for reporting environmental information within the scope of their management to the environmental management agency under the People's Committee of the province.

2. Production, business and service establishments other

${ }^{1}$ Although this information is also specified in another article, in a legal document such as Article 51 of Decree 19/2015/ND-CP February 14, 2015, than those specified in Clause 1 of this Article are responsible for providing environmental information related to their operations to the People's Committees of districts and communes.

3. Ministries and branches shall annually provide environmental information related to their respective sectors and domains to the Ministry of Natural Resources and Environment.

4. The Minister of Natural Resources and Environment shall detail this Article".

Based on the above provisions of the Law on Environmental Protection 2014, Decree 19/2015/ND-CP dated 14/02/2015 detailing the implementation of a number of articles of the Law on Environmental Protection has detailed regulations on the provision of environmental information for the community, forms of information provision and responsibility for providing information. According to Article 51 of Decree 19/2015/ND-CP:

"1. Environmental information provided periodically at least once a year includes:

a) legal documents on environment;

b) report on the current state of the national and local environment; thematic reports on the environment built and published by the state management agency in charge of natural resources and environment;

c) list of establishments causing serious environmental pollution, polluted or seriously degraded environmental areas; areas at risk of environmental incidents prepared and announced by state management agencies in charge of natural resources and environment;

d) list and information on waste sources and types of wastes that pose a risk to human health and the environment, prepared and announced by state management agencies in charge of natural resources and environment;

đ) publications, thematic publications on the environment, communication materials on the environment and related issues;

e) results of inspection, examination and handling of violations of production, business and service establishments in residential areas;

g) environmental protection activities of production, business and service establishments in residential areas;

h) Licenses related to exploitation, use and protection of natural resources and environment of production, business and service establishments in residential areas.

2. Environmental information is provided in one of the following forms:

a) documents, publications, publications are widely announced to the distribution address on the mass media;

b) posting on the official website of the state management agency in charge of natural resources and environment; project investors; owners of production, business and service establishments;

c) publicly posting at production and service establishments; headquarters of the Commune People's Committee;

d) hold a press conference to announce publicly;

đ) meetings to disseminate information to the community; 
e) other forms as prescribed by law.

3. The time to disclose information in the form specified at Points b and c, Clause 2 of this Article is at least 30 days.

4. Responsibility to provide environmental information to the residential community:

a) The state management agency in charge of environment is responsible for providing the information specified at Points a to e Clause 1 of this Article;

b) Production, business and service establishments are responsible for providing the information specified at Points $\mathrm{g}$ and $\mathrm{h}$, Clause 1 of this Article".

In addition, the regulation on consultation and supervision of the community on the environment is also a form of public information about the environment. According to Article 52 of Decree 19/2015/ND-CP, consultation may be required for the State's guidelines and policies related to the environment (such as socio-economic development plans and strategies through strategic environmental assessment consultation) and also activities that can have a direct impact on the environment (such as specific investment projects through consultations with environmental impact assessments).

In general, the basic contents of providing environmental information to the people and society have been fully regulated. However, the mechanism to enforce the right to access environmental information is still limited. Specifically:

(i) The process of providing environmental information is not clearly defined. Clause 4, Article 130 of the Law on Environmental Protection 2014 assigns the Minister of Natural Resources and Environment to provide detailed regulations on the issue of publicizing and providing environmental information, but this content is not available yet. As a result, in fact, bad information about the environment is often covered up until it is discovered, such as Vedan's stealthy discharge of waste for 14 years [18] or Formosa's case in 2016.

(ii) Most forms of publicity, providing information to the population are indirect. The only direct form is a "meeting to disseminate information to the population community" (point đ, clause 2 Article 51 of Decree 19/2015/ND-CP) which does not clearly specify the conditions for implementation, the monitoring mechanism. This makes the above "dissemination of information" activity superficial and sometimes fictitious. For example, the case of DIC Ben Tre Investment and Construction Joint Stock Company held a meeting to introduce a cement project in Loc Thuan commune, Binh Dai district, Ben Tre province on May 25, 2017. However, people thought that the organizers were not objective when "putting insiders" in to compliment the project and people's opinions were not respected, so most of them left the meeting [19].

(iii) Regulations on community consultation are still not real. For strategic environmental assessment, although Decree 19/2015/ND-CP mentions consultation, it does not stipulate how to consult. For environmental impact assessment, the regulation on consultation has specific procedures but does not show the value of consultation opinions of the community. This makes the consultation when carrying out environmental impact assessment only procedural but has no practical meaning [20].

(iv) Most of the environmental information required to be disclosed in Article 131 of the Law on Environmental
Protection 2014 is actually not public because of the lack of a binding mechanism, especially information about the environmental impact assessment reports of investment projects for production and business. This leads to a situation where environmental impact assessment reports were poorly made or copied to complete project procedures. For example, the Environmental Impact Assessment Report of the Dong Nai river encroachment project was said to have been copied from the Vinh Hang cemetery project (in Dong Nai province) [21]. In the Formosa case, the Environmental Impact Assessment Report of this company was considered to be extremely "sketchy" but still approved (only a few pages, there is no content on the marine environment, but it is still discharged to the sea) [22]. This is the reason why many production and business projects have caused serious environmental pollution or incidents. Even many environmental impact assessment reports showed signs of deception and fabrication in the appraisal when naming fictitious scientists in the appraisal committee, such as the project of sinking sewage sludge into the sea of Vinh Tan Thermal Power Plant (in Binh Thuan province) [13].

(v) The time limit for providing environmental information is not reasonable. According to Clause 1, Article 51 of Decree 19/2015/ND-CP, environmental information provided to the population at least once a year is too little, unable to update the changing status of the environment. In addition, also according to Clause 3, Article 51 of this Decree, time for information disclosure in the following forms: "Posting on the official website of the state management agency in charge of natural resources and environment; project investors; owners of production, business and service establishments; Publicly posting at production and service establishments; the headquarters of the commune-level People's Committee" at least 30 days (i.e., 30 days publicity is legal). This time is too short, not enough for people to follow and access the information they want.

(vi) Legal responsibility related to providing environmental information has not been satisfactorily regulated. In the latest regulations on administrative sanctions in the environment are in Decree 155/2016/ND-CP dated November 18, 2016 (amended by Decree 55/2021/ND-CP dated May 24, 2021) there are only a few provisions on penalties for violations of regulations on environmental information disclosure (Article 31, 36, 45, 46), mainly related to waste products and genetically modified food. Most of the environmental information required to be disclosed under Article 131 of the Law on Environmental Protection 2014 for both state agencies and business entities has not been subject to specific sanctions. This is the reason why important information about the environment is so difficult to access in practice [23].

\section{Potential Barriers to Information Access from the Provisions of the Law on Environmental Protection 2020}

As mentioned above, the Law on Environmental Protection 2020 (effective from January 1, 2022) has eliminated the term "environmental security". This is a serious concern for environmental protection policies. In addition, the concept of environmental information is no longer officially explained as in the provisions of the Law on Environmental Protection 2014, but only environmental information is listed (Article 
114 of the Law on Environmental Protection 2020). In addition, the Law on Environmental Protection 2020 does not have general regulations on environmental information disclosure as prescribed in Article 131 of the Law on Environmental Protection 2014. However, the Law on Environmental Protection 2020 does mention the requirement for publicity in environmental protection activities. Specifically, Clause 4, Article 4 of the Law on Environmental Protection 2020 (in terms of environmental protection principles) stipulates that, "Environmental protection activities must be conducted regularly, openly and transparently; Prioritize forecasting, preventing pollution, incidents, environmental degradation, managing environmental risks, minimizing waste generation, increasing reuse and recycling of waste to exploit the resource values of waste." The requirement of "publicity and transparency" in the above regulation can be inferred from the compulsory disclosure of environmental information, but it lacks persuasiveness and is not commensurate with the requirement for information disclosure specified in Article 131 of the Law on Environmental Protection 2014.

Although in terms of the number of provisions and cases in which environmental information must be disclosed, the Law on Environmental Protection 2020 has nearly twice the content of the provisions of the Law on Environmental Protection 2014, but the provisions of the Law on Environmental Protection 2020 on this issue also set certain problems. Firstly, it lacks the "transparency" and generalization of environmental information disclosure as stipulated in Article 131 of the Law on Environmental Protection 2014; Secondly, there are quite a few provisions in the Law on Environmental Protection 2020 that allow the exclusion of responsibility for information disclosure if it is related to state secrets and "enterprise secrets" (Article 43, 47, 48), while the Law on Environmental Protection 2014 only does not allow the disclosure of information in cases of state secrets and national defense and security secrets. Therefore, the provisions of the Law on Environmental Protection 2020 can be "abused" to not publicize environmental information in accordance with the law. Meanwhile, relevant laws (such as the Enterprise Law, the Intellectual Property Law) only regulate trade secrets and business secrets, but do not refer to "enterprise secrets" in general as provisions of the Law on Environmental Protection 2020. According to the author's personal opinion, even in the case of business secrets of enterprises that have been registered for protection, if it is necessary to publicize information for environmental protection related to business activities, their business, the State should also take into consideration. If business activities are likely to cause serious damage to the environment that can only be prevented by means of information disclosure, the State and enterprises must choose between not doing business or doing business and must disclose relevant environmental information. This is a very difficult thing for both of these subjects, but to ensure environmental security, it must be done.

\section{CONCLUSIONS AND RECOMMENDATIONS}

Completely, timely and accurately Accessing to environmental information is a prerequisite for people to contribute to protecting their healthy living environment and thereby ensuring environmental security. These requirements can only be fulfilled when mechanisms to ensure the right to access environmental information are fully regulated. Based on the above situation, the author has the following recommendations to solve the above requirements:

(i) The law should have provisions forcing state management agencies in charge of environment to publicize reports on strategic environmental assessment and environmental impact assessment within 15 days from the date of receipt of these approved reports. Publication period is during the implementation of a master plan, plan, strategy, or investment project. This disclosure must be published in the press and on the websites of the aforementioned state agencies.

(ii) The publicity about waste and waste treatment of production and business entities must be done monthly on their website. In the event that there are signs of environmental pollution caused by these entities, they must immediately provide all information on waste management to the affected communities when there is a need.

(iii) Adjustment of regulations on information disclosure time in Article 51 of Decree 19/2015/ND-CP. In my opinion, the disclosure of information for the cases specified in Clause 1, Article 51 of this Decree must be at least three times a year. For the information in Clause 3, Article 51 of Decree $19 / 2015 / \mathrm{ND}-\mathrm{CP}$, the time limit for information disclosure must be at least 6 months, not just 30 days as the current regulations.

(iv) Specifying the legal responsibilities of state agencies and other entities responsible for providing environmental information. All information that is required to be made public or must be provided on request that the obligee does not provide or provides is inaccurate or dishonest, shall bear appropriate legal responsibility.

According to Article 7 of the Law on Environmental Protection 2014, among the acts that are strictly prohibited by law, the following acts are prescribed: "Concealing acts of environmental destruction, obstructing environmental protection activities, falsifying information leading to causing harm negative consequences for the environment". In order for this regulation to take effect, the mechanism for providing information as well as sanctions for violations of the provision of environmental information must be completed soon.

From January 1, 2022, Vietnam will apply the Law on Environmental Protection 2020. The regulation on information disclosure in the Law on Environmental Protection 2020 has some new and progressive points but also contains many limitations. If compared with the Law on Environmental Protection 2014, it is difficult to confirm which of the provisions of the Law is better, especially when the Law on Environmental Protection 2020 has not been implemented in practice and there is no document on implementation. Unfortunately, the Law on Environmental Protection 2020 was born in the context that the Law on Protection of State Secrets 2018 has just taken effect (July 1, 2020), in which stipulates that "information about natural 
resources and environment including water resources, environment, geology, minerals, hydrometeorology, land, sea, islands, surveying and cartography" may be state secret (Clasue 6 Article 7). Perhaps this is reason makes the regulations on information disclosure in the Law on Environmental Protection 2020 more "conservative" than the provisions of the previous Law. It is hoped that the implementing regulations of the Law on Environmental Protection 2020 will overcome the limitations of the previous law to remove doubts about the accessibility of environmental information in Vietnam, thereby contributing to ensuring the necessary environmental security. To do this, Vietnam should also refer to the content of the Aarhus Convention to make the appropriate provisions for ensuring access to environmental information.

\section{REFERENCES}

[1] Ta Dinh Thi, Phan Thi Kim Oanh, Ta Van Trung, Bui Duc Hieu, Ensuring environmental security in Vietnam - Urgent issues to be solved, Vietnam Climate Change Journal, 2017, No. 2, pp. 7-15.

[2] Tran Nguyen Tuyen, Some current environmental problems in Vietnam - current situation and solutions, 2021.http://hdll.vn/vi/nghien-cuu-trao-doi/mot-so-van-de-ve-moi-truong-o-viet-nam-hien-nay--thuctrang-va-giai-phap.html, accessed July 13, 2021.

[3] Thai Anh Hung, International law on the right to access information, 2015. https://noichinh.vn/nghien-cuu-trao-doi/201505/phap-luat-quocte-ve-quyen-tiep-can-thong-tin-297557/, accessed July 13, 2021.

[4] Vo Minh Tap, Sustainable development - some issues of theory and strategy implementation in the first two decades of the 21 st century, 2018. https://css.hcmussh.edu.vn/?ArticleId=68a55120-f7cd-467f877b-86744555464e, accessed July 15, 2021.

[5] Vietnamese Law on Environmental Protection 2014.

[6] European Commision, Aarhus Convention, https://ec.europa.eu/environment/aarhus/, accessed July 16, 2021.

[7] Le Thi Thanh Ha, Environmental security issues in Vietnam today, 2018. http://tuyengiao.vn/nghien-cuu/ly-luan/van-de-an-ninh-moitruong-o-viet-nam-hien-nay-115852, acceessed July 14, 2021.

[8] G. Zurlini, F. Müller, in Encyclopedia of Ecology, Environmental security, 2008. https://www.sciencedirect.com/topics/earth-andplanetary-sciences/environmental-security, acceessed July 14, 2021.

[9] Truong Hong Quang, Basic content of the law on the right to access information, 2016. http://moj.gov.vn/qt/tintuc/Pages/nghien-cuu-traodoi.aspx?ItemID=1915, accessed July 12, 2021.

[10] Nguyen Ngoc Sinh and Nguyen Dinh Hoe, 10 warnings about Vietnam's environmental security, http://www.vacne.org.vn/10-canhbao-ve-an-ninh-moi-truong-viet-nam/29919.html, accessed July 12 , 2021.

[11] Nghia Nhan, Why did Formosa install an underground pipeline to discharge waste into the sea? 2016. https://plo.vn/thoi-su/vi-saoformosa-dat-duong-ong-ngam-xa-thai-ra-bien-627324.html, accessed July 13, 2021.

[12] RFI, Vietnam: Protests in many places mark a year of the Formosa disaster, 2017. https://www.rfi.fr/vi/viet-nam/20170407-viet-nam- bieu-tinh-o-nhieu-noi-danh-dau-mot-nam-tham-hoa-formosa, accessed July 13, 2021.

[13] Chi Nhan, Le Quan, Phan Hau, Records of sinking 1 million m3 of sludge: impersonating many scientists, 2017. https://thanhnien.vn/taichinh-kinh-doanh/ho-so-nhan-chim-1-trieu-m3-bun-thai-mao-danhnhieu-nha-khoa-hoc-857980.html, accessed July 13, 2021.

[14] Lan Huong, RFA, Threat of marine environment from sludge of Vinh Tan 1, 2017. https://www.rfa.org/vietnamese/in_depth/the-risk-ofmarine-environment-damage-from-the-sludge-of-thermal-powerplant-vinh-tan-one-07012017113356.html, accessed July 13, 2021.

[15] Vietnamese Law on Environmental Protection 2005.

[16] Phan Song Ngan, Announcement of the list of "cancer villages" with heavy water pollution, 2015.

https://stnmt.quangbinh.gov.vn/3cms/cong-bo-danh-sach$\%$ E2\%80\%9Clang-ung-thu\%E2\%80\%9D-o-nhiem-nang-nguonnuoc.htm, accessed July 14, 2021.

[17] Nguyen Van Cuong, Exercising the right to access environmental information, 2017.

http://daibieunhandan.vn/default.aspx?tabid=81\&NewsId=351831, accessed July 10, 2021.

[18] Minh Quang, Vedan "killed" Thi Vai river, 2008 https://tuoitre.vn/vedan-giet-song-thi-vai-278294.htm, accessed July $15,2021$.

[19] Mau Truong, Suspicious that the organizers "installed insider" to praise the project, people left, http://tuoitre.vn/tin/chinh-tri-xahoi/20170725/cho-la-ban-to-chuc-cai-nguoi-khen-du-an-dan-bove/1358101.html, accessed July 15, 2021.

[20] Nguyen Khac Kinh, The lack of substance in the environmental assessment consultation, 2015. https://www.thiennhien.net/2015/06/04/tham-van-trong-danh-giamoi-truong-con-thieu-thuc-chat/, accessed July 10, 2021.

[21] Thu Hang, The project to encroach on the Dong Nai River must be canceled, 2015. https://thanhnien.vn/thoi-su/phai-huy-bo-du-an-lapsong-dong-nai-561717.html, accessed July 15, 2021.

[22] Nguyen Hoai, Formosa's environmental impact assessment: Startled, 2016. http://www.tienphong.vn/xa-hoi/danh-gia-tac-dong-moi-truongcua-formosa-giat-minh-1029013.tpo, accessed June 30, 2021.

[23] Decree 179/2013/ND-CP on sanctioning administrative violations in the field of environment was in a similar situation.

[24] Aarhus Convention 1998 (the UNECE Convention on Access to Information, Public Participation in Decision-making and Access to Justice in Environmental Matters)

[25] Declaration of the United Nations Conference on the Human Environment, Stockholm 1972.

[26] Rio Declaration on Evironment and Development, Rio de Janeiro 1992

[27] Vietnamese Law on Environmental Protection 2020.

[28] Decree 19/2015/ND-CP February 14, 2015 Detailing the implementation of a number of articles of the law on environmental protection.

[29] Decree 55/2021/ND-CP dated May 24, 2021 of the Government amending and supplementing a number of articles of the Government's Decree No. 155/2016/ND-CP dated November 18, 2016 providing for the sanctioning of administrative violations in the domain of environmental protection.

[30] Nguyen Hoai, Tien Phong Newspape, Contaminated village: children with lead in their blood, 2013. https://tienphong.vn/lang-o-nhiemnhung-dua-tre-mang-chi-trong-mau-post642022.tpo, accessed July 10 2021. 